\title{
PENGARUH FOREIGN DIRECT INVESTMENT (FDI) TERHADAP PERTUMBUHAN EKONOMI DI NUSA TENGGARA BARAT TAHUN 2010-2014
}

\section{The Effect of Foreign Direct Investment on the Economic Growth of West Nusa Tenggara Province within 2010-2014}

\author{
Munyta Mentari ${ }^{1}$; Abdul Hadi Ilman ${ }^{1}$; Didi Suwardi' \\ ${ }^{1}$ Program Studi Ekonomi Pembangunan, Fakultas Ekonomi dan Bisnis, Universitas Teknologi Sumbawa \\ *)E-mail : mentarimunyta@gmail.com
}

\begin{abstract}
This research aims to analyse the effect of Foreign Direct Investment (FDI) on the economic growth of West Nusa Tenggara (NTB) province within 2010-2014. The dependent variable is economic growth, meanwhile the independent variables are : 1) FDI proxied from the percentage of foreign capital investment towards PDRB; 2) Schooling or level of education proxied from the percentage of up to 15 years-old people who complete senior high school education level; 3) Domestic investment proxied from the percentage of domestic capital investment towards PDRB; 4) The interaction of FDI and human capital (level of education) and the control variables which consist of APBD proxied from the percentage of APBD towards PDRB and inflation variable proxied from PDRB deflator. Data analysis used in this study is regression model of panel data. The data is obtained from 10 districts and cities in NTB province from 2010 to 2014. The chow test and hausman test resulted to use fixed effect model in that panel data regression procedure. The results show that FDI has a positive yet unsignificant effect on the economic growth with the confidence level of $95 \%$. It is caused by the low level of technological transfer by the province human resources due to the domination of less educated workers.
\end{abstract}

Keywords: Foreign Direct Investment, economic growth, human capital, technological transfer

\begin{abstract}
ABSTRAK
Penelitian ini bertujuan untuk menganalisis pengaruh Foreign Direct Investment (FDI) terhadap pertumbuhan ekonomi di Provinsi Nusa Tenggara Barat pada tahun 2010-2014. Variabel dependen dalam penelitian ini adalah pertumbuhan ekonomi dan variabel independen antara lain: FDI yang diproksi dari persentase penanaman modal asing terhadap PDRB, Schoolig atau tingkat pendidikan yang diproksi dari persentase pendduk usia 15 tahun keatas yang menamatkan pendidikan hingga tingkat SLTA, investasi domestik yang diproksi dari persentase pananaman modal dalam negeri terhadap PDRB, interaksi antara FDI dengan human capital (tingat pendidikan), serta variabel kontrol yang terdiri dari APBD yang diproksi dari persentase APBD terhadap PDRB dan variabel inflasi yang diproksi melalui PDRB deflator. Analisis data menggunakan model regresi data panel dengan mengambil sampel 10 Kabupaten dan Kota di Provinsi NTB dari tahun 2010-2014. Hasil uji chow dan uji hausman menunjukkan bahwa pendekatan yang digunakan dalam regresi data panel tersebut adalah fixed effect model. Sehingga hasil estimasi menunjukkan bahwa FDI berpengaruh positif dan tidak signifikan terhadap pertumbuhan ekonomi dengan tingkat kepercayaan $95 \%$. Hal ini disebabkan karena rendahnya kemampuan transfer teknologi oleh sumber daya manusia di provinsi NTB mengingat angkatan kerja didominasi oleh pekerja lulusan SD.
\end{abstract}

\section{Kata Kunci : Foreign Direct Investment, pertumbuhan ekonomi, human capital, transfer teknologi}

\section{Pendahuluan}

Pertumbuhan ekonomi menunjukkan sejauh mana aktivitas perekonomian akan menghasilkan tambahan pendapatan masyarakat pada suatu periode tertetu. Aktivitas perekonomian merupakan proses pengunaan faktor-faktor produksi untuk menghasilkan output, sehingga pada akhirnya akan memberikan balas jasa terhadap faktor produksi yang dimiliki masyarakat (Mankiw,2008).
Peningkatan pertumbuhan ekonomi tidak terlepas dari peran investasi baik itu investasi domestik maupun investasi asing. Investasi atau penanaman modal merupakan suatu kegiatan membentuk nilai tambah, dengan melakukan pembelian barang modal dan perlengkapan produksi untuk menambah nilai barang dan jasa yang tersedia dalam perekonomian. Investasi merupakan "engine of growth" karena berperan penting dalam 
perekonomian, terutama bagi negara dengan sistem ekonomi terbuka untuk meningkatkan pertumbuhan ekonomi (Sutawijaya, 2013). Penelitian ini berfokus pada peran foreign direct investment dalam upaya peningkatan pertumbuhan ekonomi.

Berdasarkan undang-undang No 25 tahun 2007 tentang penanaman modal pasal (1) butir (3) menyatakan bahwa penanaman modal asing adalah kegiatan penanaman modal untuk melakukan usaha di wilayah Negara Republik Indonesia yang dilakukan oleh penanaman modal asing baik yang menggunakan modal asing sepenuhnya maupun sebagain modal dalam negeri. Baik dalam bentuk penanaman modal asing langsung atau pun dengan melakukan pembelian saham perusahaan tertentu di Indonesia.

FDI meningkatkan pertumbuhan ekonomi melalui 2 cara yaitu akumulasi kapital dan peningkatan produktifitas faktor produksi melalui difusi teknologi. FDI dianggap sebagai saluran utama untuk mengakses kemajuan teknologi yang diterapkan oleh negara-negara maju. Teknologi merupakan penentu utama laju pertumbuhan ekonomi dalam jangka panjang dengan mengadopsi teori pertumbuhan endogen. Akan tetapi penerapan teknologi yang lebih maju mensyaratkan tingkat modal manusia yang cukup dan mampu dalam menyerap teknologi yang masuk. Penerapan teknologi maju dan kemampuan penyerapan oleh sumber daya manusia merupakan faktor penentu pertumbuhan ekonomi. Sehingga, adanya interaksi yang kuat antara FDI dengan modal manusia yang tersedia. Kontribusi FDI terhadap pertumbuhan ekonomi ditingkatkan oleh interaksinya terhadap tingkat sumber daya manusia (E.Borenztein dkk, 1998)

Berdasarkan data yang dirilis oleh BPS Prov. NTB 2014, tercatat bahwa laju petumbuhan ekonomi NTB di tahun 2016 tertinggi di banding laju pertumbuhan ekonomi nasional yaitu sebesar 5,37\% dan pertumbuhan ekonomi nasional hanya mencapai $5,21 \%$. Hal ini sejalan dengan tingkat investasi asing langsung di NTB dari 2010 - 2014 terus mengalami peningkatan. Tercatat pada tahun 2010 jumlah investasi sebesar Rp 1.641,78 milyar, pada tahun 2011 investasi meningkat menjadi Rp 1.777,63 milyar hingga tahun 2014 investasi terus meningkat hingga mencapai angka Rp 9.999,29 milyar. Selengkapnya dapat dilihat pada gambar 1 berikut:

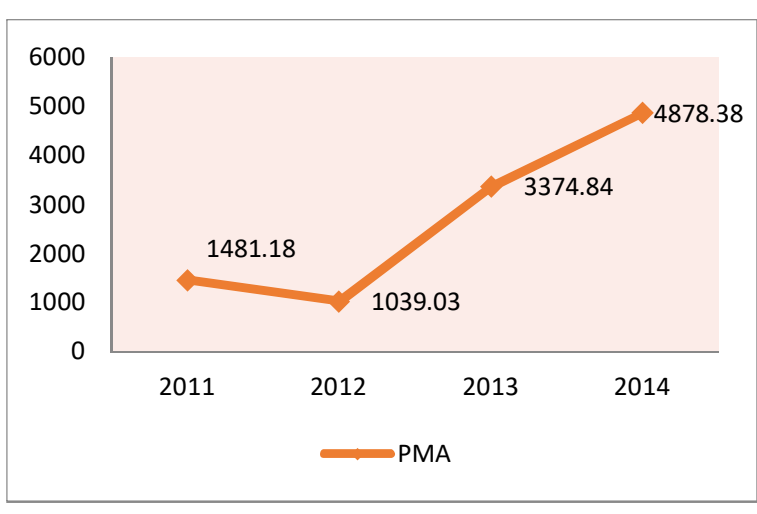

Gambar 1. Perkembangan Realisasi FDI tahun 2010-2014 (http://bkpm-ptsp.ntbprov.go.id)

Peningkatan laju investasi dari tahun 2011 sampai dengan tahun 2014, dimana tercata laju investasi tahun 2011 adalah 9\%, tahun 2012 sebesar $8.27 \%$. Dan terjadi peningkatan yang sangat signifikan pada tahun 2013 dan 2014 yaitu sebesar 44\% dan 97\%. hal ini disebabkan karena peningkatan iklim investasi dan realisasi investasi yang kondusif. Adanya relaksasi untuk pertambangan dalam mengekspor konsentrat tembaga. Dan hal lain pula terjadi investasi pada sektor pariwisata, energy dan kelistrikan (Kajian Ekonomi dan Keuangan Daerah Prov.NTB, 2014).

Peningkatan pada FDI juga berdasarkan beberapa motivasi antara lain : Pertama market-seeking, ketersediaan pasar domestik dan pada umumnya dihubungkan antara ukuran pasar dengan pendapatan perkapita, pertumbuhan ekonomi, akses perdagangan antar negara sekitar, dan selera dari masyarakat negara yang akan di pilih. Kedua resource-asset, berdasarkan jumlah bahan baku seperti sumber daya alam, biaya tenaga kerja, angkatan kerja, tenaga kerja terampil, infrastruktur fisik (jalan, pelabuhan, dan telekomunikasi), dan teknologi. Terakhir yaitu efficiency-seeking yaitu biaya produksi yang lebih rendah dalam melakukan produktivitasnya (Fachriza, 2015).

Salsabila (2013) mengatakan bahwa pengaruh FDI terhadap pertumbuhan ekonomi di Indonesia tidak dapat serta merta memberikan dampak positif, karena berdasarkan berbagai literatur bahwa FDI berinteraksi secara kompleks dengan berbagai faktor pada suatu wilayah sebelum dapat berkontribusi terhadap pertumbuhan ekonomi. FDI yang masuk nyatanya harus berinteraksi dengan pasar tenaga kerja sehingga para tenaga kerja mendapatkan keterampilan dan pengetahuan dari adanya transfer teknologi akibat adanya FDI yang bersifat berkelanjutan bahkan ketika FDI sudah tidak berada lagi pada wilayah tersebut.

Agma (2015) mengatakan pertumbuhan ekonomi meliputi peningkatan dan mendorong kemakmuran serta kesejahteraan rakyat. Pertumbuhan ekonomi tidak terlepas dari adanya investasi terutama bagi 
negara berkembang. Adanya FDI meningkatkan pertumbuhan ekonomi melalui peningkatan sumberdaya manusia yang ahli dalam bidangnya, peningkatan infrastruktur dalam pembuatan jalan untuk membantu mendistribusikan hasil produksi, serta meningkatkan tingkat ekspor.

Perbedaan antara kedua pendapat dan latar belakang diatas, sehingga peneliti ingin menganalisis pengaruh dari adanya peningkatan FDI secara terusmenerus dari tahun 2010-2014 di Provinsi NTB terhadap pertumbuhan ekonomi.

Berdasarkan uraian diatas, maka permasalahan yang akan diteliti dalam penelitian ini adalah:

1. Bagaimana pengaruh FDI terhadap pertumbuhan ekonomi di provinsi Nusa Tenggara Barat 20102014 ?

2. Bagaimana pengaruh kapasitas sumber daya manusia di NTB untuk menyerap FDI sehingga dapat mendorong pertumbuhan ekonomi ?

Adapun tujuan penelitian yang ingin dicapai dalam penelitian ini antara lain :

1. Untuk menganalisis pengaruh FDI terhadap pertumbuhan ekonomi di Provinsi Nusa Tenggara Barat 2010-2014

2. Untuk menganalisis pengaruh kapasitas sumber daya manusia di NTB untuk dapat menyerap FDI sehingga dapat berpengaruh terhadap pertumbuhan ekonomi

\section{Metode Penelitian}

Dalam penelitian ini peneliti menggunakan metode penelitian kuantitatif deskriptif. Metode deskriptif kuantitatif adalah untuk menganalisi potensi ekonomi dengan cara mengukur variabel-variabel ekonomi yang terkait berdasarkan teori pertumbuhan ekonomi.

Data yang digunakan dalam penlelitian ini antara lain pertumbuhan ekonomi sebagai variabel dependen, data penanaman modal asing yang diproksi dari persentase FDI terhadap PDRB. pendidikan yang diproksi dengan persentasi pendudukan dengan pendidikan terakhir SLTA, PDRB per kapita, interaksi antara FDI dan human capital, data penenaman modal dalam negeri diproksi dengan persentasi terhadap PDRB. Data PDRB untuk mengukur tingkat inflasi dengan menggunakan PDRB deflator. Data APBD yang diproksi dari persentasi PDRB terhadap PDRB setiap kabupaten dan kota yang terdapat pada provinsi Nusa Tenggara Barat tahun 2010-2011. Sumber data dalam penelitian ini adalah data skunder dari beberapa instansi antara lain Bank Indonesia, Badan Pusat Statistik Prov. NTB, Badan Perizinan dan Penanaman Modal Terpadu Provinsi NTB.

\section{Model Regresi Data Panel}

Untuk menganalisis pengaruh FDI terhadap pertumbuhan ekonomi, digunakan persamaan produksi pada teori pertumbuhan endogen. Dimana determinan penting pertumbuhan PDRB adalah technical progress, kenaikan penawaran tenaga kerja, dan akumulasi modal. Sehingga persamaan sebagai berikut (Dornbusch, 2008):

$$
Y=A K^{\theta} N^{1-\theta}
$$

Dimana A adalah teknologi, K adalah kapital, dan N stok tenaga kerja.. Oleh karena itu diperoleh persamaan sebagai berikut :

$$
\begin{aligned}
& g=\beta_{0}+\beta_{1} \mathrm{FDI}_{\mathrm{it}}+\beta_{2} \mathrm{PI}_{\mathrm{it}}+\beta_{3} \mathrm{H}_{\mathrm{it}}+\beta_{4} \text { Invest }_{\mathrm{it}}+ \\
& \beta_{6} \mathrm{FDI}^{*} \mathrm{H}+\beta_{5} \mathrm{~A}_{\mathrm{it}}+\mathrm{e}_{\mathrm{it}} \\
& \text { dimana : } \\
& \mathrm{g}=\text { Pertumbuhan Ekonomi (\%) } \\
& \beta_{0} \quad=\text { Konstanta } \\
& \text { FDI = Persentase Foregn Direct Investment terhadap } \\
& \text { PDRB } \\
& \text { PI = Personal Income / PDRB per Capita (Rupiah) } \\
& H \quad=\text { Human Capital / Pendidikan (\%) } \\
& \text { Invest } \quad=\text { Persentase investasi domestik terhadap PDRB (\%) } \\
& \text { FDI*H = Interaksi antara FDI dan Human Capital (\%) } \\
& A \quad=\text { Variabel control terdiri dari Inflasi }(\%) \text { dan } \\
& \text { persentase APBD Terhadap PDRB (\%) } \\
& \beta_{1}, \beta_{2}, \beta_{3}=\text { Koefisien regresi masing-masing variabel } \\
& i \quad=\text { Cross section data panel } \\
& t \quad=\text { time series } \\
& \text { et } \quad=\text { errorterm }
\end{aligned}
$$

Ada 3 teknik pendekatan mendasar yang digunakan dalam mengestimasi model regresi dengan data panel, yaitu:

\section{1. $\quad$ Model Pooled Least Square (Common Effect)}

Merupakan pendekatan model data panel yang paling sederhana karena hanya mengkombinasikan data time series dan cross section. Pada model ini tidak diperhatikan dimensi waktu maupun individu, sehingga diasumsikan bahwa perilaku data perusahaan sama dalam berbagai kurun waktu. Metode ini bisa menggunakan pendekatan Ordinary Least Square (OLS) atau teknik kuadrat terkecil untuk mengestimasi model data panel.

\section{Model Pendekatan Efek Tetap (Fixed Effect)}

Model ini mengasumsikan bahwa perbedaan antar individu dapat diakomodasi dari perbedaan intersepnya. Untuk mengestimasi data panel model Fixed Effects menggunakan teknik variable dummy untuk menangkap perbedaan intersep antar perusahaan, perbedaan intersep bisa terjadi karena perbedaan budaya kerja, manajerial, dan insentif. Namun demikian slopenya sama antar perusahaan. Model estimasi ini sering juga disebut dengan teknik Least Squares Dummy Variable (LSDV). 
3. Model Pendekatan Efek Acak (Random Effect).

Model ini akan mengestimasi data panel dimana variabel gangguan mungkin saling berhubungan antar waktu dan antar individu. Pada model Random Effect perbedaan intersep diakomodasi oleh error terms masing-masing perusahaan. Keuntungan menggunakan model Random Effect yakni menghilangkan heteroskedastisitas. Model ini juga disebut dengan Error Component Model (ECM) atau teknik Generalized Least Square (GLS).

\section{Pemilihan Model Estimasi Data Panel}

Pengujian secara formal untuk menentukan model yang lebih baik digunakan berdasarkan keputusan statistik. Serangkaian pengujian statistik yang dapat dilakukan terdiri dari beberapa langkah, antara lain:

\section{Chow Test}

Chow test (pengujian F-statistik) berfungsi untuk menentukan apakah model yang digunakan Pooled Least Square atau Fixed Effect. Dalam pengujian ini dilakukan dengan hipotesis sebagai berikut:

\section{H0 : Model Pooled Least Square (restricted) \\ H1 : Model Fixed Effect (unrestricted)}

Tolak Ho jika nilai chow test statistic (F-statistik) lebih besar dari F table atau Prob F < alfa. Dengan demikian model yang dipilih adalah model fixed effect, dan sebaliknya. Jika Prob F > alfa makan model yang dipilih adalah Pooled Least Square

\section{Lagrange Multiplier (LM) Test}

Lagrange Multiplier (pengujian F-statistik) berfungsi untuk menentukan apakan model yang digunakan Pooled Least Square atau Random Effect. Dalam pengujian ini dilakukan dengan hipotesis sebagai berikut:

\section{Ho: Pooled Least Square \\ H1 : Random Effect}

Tolak Ho jika nilai lagrange multiplier test statistic (F-statistik) lebih besar dari F table atau Prob F < alfa.

Dengan demikian model yang dipilih adalah model Random Effect, dan sebaliknya. Jika Prob F > alfa maka model yang dipilih adalah Pooled Least Square.

\section{Hausman Test}

Pengujian ini dilakukan untuk menentukan apakah model fixed effect atau random effect yang dipilih. Pengujian ini dilakukan dengan hipotesis berikut:

\section{Ho: Model random effect \\ H1 : Model fixed effect}

Dasar penolakan Ho adalah dengan menggunakan pertimbangan statistik chi square. Jika chi square statistic $>$ chi square table $(p$-value $<\alpha)$ maka Ho ditolak (model yang digunakan adalah fixed effect) dan sebaliknya.

\section{Uji Asumsi Klasik}

Dengan pemakaian metode pooled least square dan fixwd effect untuk menghasilkan nilai parameter model penduga yang lebih tepat, maka diperlukan pendeteksian apabila terdapat penyimpangan dari asumsi klasik, yang terdiri dari :

\section{Uji Mutikolinearitas}

Adalah untuk melihat ada atau tidaknya korelasi yang tinggi antara variabel-variabel independen dalam satu model. Alat statistic yang digunakan untuk menguji gangguan multikolinearitas adalah dengan ketentuan, jika nilai varian inflation factor (VIF) tidak lebih 10 dan nilai tolerance tidak kurang dari 0.1 , agar terbebas dari multikolinearitas.

2. Uji Autokorelasi

Dilakukan untuk mengetahui apakah dalam model regresi terdapat masalah autokorelasi atau tidak.

\section{Uji Heteroskedastisitas}

Adalah untuk melihat apakah terdapat ketidaksamaan varians dari residual satu pengamatan dengan pengamatan lainnya. Untuk mengetahui ada tidaknya heteroskedastisitas dibuktikan dengan nilai (Prob $>$ chi) $>$ alfa.

\section{Hasil Analisis dan Pembahasan}

\section{Penentuan Teknik Analisis Data Panel}

\section{Uji Chow}

Tabel 1. Hasil Chow Test

\begin{tabular}{ll}
\hline Chow test & Hasil \\
\hline Nilai Probabilitas F & 0.0000 \\
Keputusan & Fixed Effect \\
\hline Sumber: Data sekunder diolah, 2017
\end{tabular}

\section{Uji Hausman}

Tabel 2. Uji Hausman Test

\begin{tabular}{ll}
\hline Hausman test & Hasil \\
\hline Nilai Probabilitas $>$ Chi2 & 0.0001 \\
Keputusan & Fixed Effect \\
\hline
\end{tabular}

Sumber: Data sekunder diolah, 2017

Berdasarkan hasil uji chow dan uji hausman tersebut, maka pendekatan yang digunakan untuk melakukan estimasi pada persamaan adalah model fixed effect.

\section{Hasil Uji Asumsi Klasik}

Dengan pemakain metode fixed effect, untuk menghasilkan nilai parameter model penduga yang 
lebih tepat, maka diperlukan pendeteksian apakah terjadi penyimpangan pada asumsi klasik atau tidak.

\section{Uji Multikolinearitas}

Tabel 3. Uji Multikolinearitas

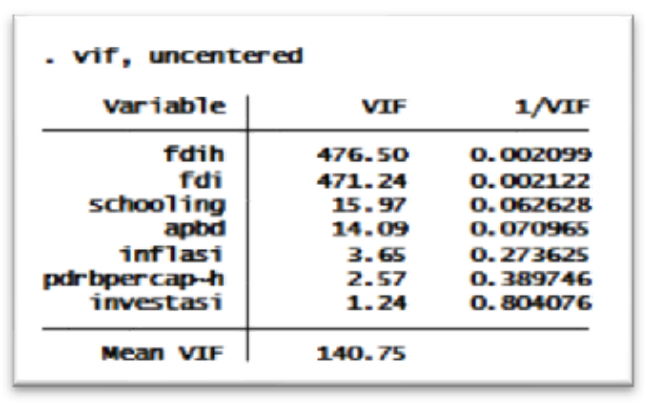

Sumber: Data sekunder diolah, 2017

Hasil diatas menunjukkan bahwa adanya multikolinearitas yang kuat antara variabel independen FDI*H, FDI, schooling atau tingkat pendidikan dan APBD terhadap pertumbuhan ekonomi karena memiliki nilai VIF lebih besar dari 10 yaitu FDI*H sebesar 476.50, FDI sebesar 471.24 pada variabel schooling sebesar 11.53 dan APBD sebesar 10.58

2. Uji Heteroskedastisitas

Tabel 4. Uji Heteroskedastisitas

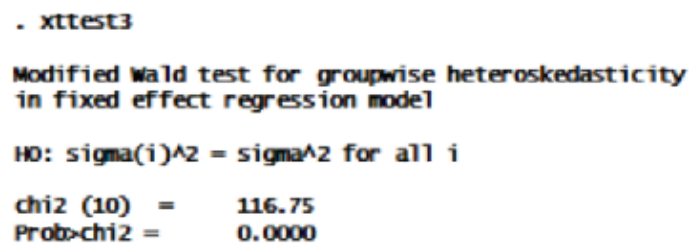

Sumber: Data sekunder diolah, 2017

Hasil tabel 4 menunjukkan bahwa (Prob $>$ chi2) $<$ alfa (0.05) maka hal ini menunjukkan adanya heteroskedastisitas yang kuat antar variabel, sehingga varian dari residual satu pengamatan ke pengamatan lain adalah tidak tetap

3. Uji Autokorelasi

Tabel 5. Uji Autokorelasi

Sumber: Data sekunder diolah, 2017

Berdasarlkan hasil pada gambar 4.6 dimana uji autokorelasi antar variabel menunjukkan hasil Prob $\mathrm{F}>$ alfa (0.05) yaitu sebesar 0.2695. sehingga dapat diambil kesimpulan bahwa pada model estimasi tidak adanya autokorelasi yang kuat antar variable

\section{Uji F (Uji Global)}

Tabel 6. Uji R-Square

\begin{tabular}{ll}
\hline R- Square Within & 0.9386 \\
R- Square Between & 0.8188 \\
R- Square overall & 0.0962 \\
\hline Sumber: Data sekunder diolah, 2017
\end{tabular}

Pada estimasi dengan menggunakan model fixed effect dalam mengestimasi $\mathrm{R}^{2}$ yang digunakan adalah $\mathrm{R}^{2}$ within. Hasil pada tabel 4.1 menunjukkan bahwa variabel independen yaitu FDI, pendapatan perkapita, lama pendidikan, investasi dalam negeri, interaksi FDI terhadap human capital dan variabel pengontrol yang terdiri dari inflasi dan APBN secara bersama-sama dapat menjelaskan variabel dependen yaitu pertumbuhan ekonomi sebesar $93.86 \%$. atau $94 \%$

\section{Uji T (Uji Partial)}

Tabel 7. Fixed Effect Robust Model (Uji Parsial)

\begin{tabular}{|c|c|c|}
\hline G & Coef & $P>|t|$ \\
\hline Fdi & .0791246 & 0.249 \\
\hline Schooling & .4133332 & 0.001 \\
\hline Pdrbpercapita h & 4.38-e07 & 0.000 \\
\hline Apbd & .1283322 & 0.529 \\
\hline Inflasi & -.4748451 & 0.031 \\
\hline Fdi*h & .0062149 & 0.101 \\
\hline Investasi & .0090216 & 0.888 \\
\hline cons & -23.18179 & 0.000 \\
\hline
\end{tabular}

Tabel diatas menggunakan pendekatan Fixed effect model dengan melakukan uji secara parsial antar variabel independen dengan variabel dependen. Konstanta pada persamaan diatas menunjukkan bahwa apabila nilai dari variabel independen yaitu FDI, pendapatan per kapita, schooling, investasi domestik, inflasi dan APBD bernilai nol, maka nilai dari pertumbuhan ekonomi (g) adalah $-23.18179 \%$. Variabel independen FDI (foreign direct investment) yang diproksi dari persentase FDI terhadap PDRB perpengaruh positif tetapi tidak signifikan terhadap pertumbuhan ekonomi dengan Prob $>\mathrm{t}$ lebih besar dari 0.05 yaitu sebesar 0.249 dengan tingkat kepercayaan 95\%. Sehingga apabila apabila terjadi peningkatan foreign direct investment sebesar satu persen dengan asumsi bahwa variabel independen yang lain tetap, maka akan berpengaruh positif terhadap pertumbuhan ekonomi sebesar $0.0791246 \%$

Variabel independen Schooling yang diproksi dari persentase jumlah penduduk usia diatas 10 tahun keatas dengan pendidikan terakhir yang ditamatkan hingga jenjang SLTA berpengaruh positif dan signifikan terhadap variabel dependen pertumbuhan ekonomi dengan Prob $>$ t lebih kecil dari 0.05 yaitu sebesar 0.000 . Sehingga apabila terjadi peningkatan pada persentasi penduduk yang tamat SLTA sebesar satu persen dengan asumsi bahwa variabel 
independen yang lain tetap, maka akan berpengaruh positif terhadap pertumbuhan ekonomi sebesar $0.44133332 \%$. Dengan kata lain apabila terjadi peningkatan pada persentase penduduk yang tamat hingga tingkat SLTA sebesar satu persen maka akan meningkatkan pertumbuhan ekonomi sebesar $0.44133332 \%$

Variabel independen pendapatan per kapita yang diproksi dari PDRB per kapita berpengaruh positif dan signifikan terhadap variabel dependen pertumbuhan ekonomi dengan Prob $>\mathrm{t}$ lebih kecil dari 0.05 yaitu sebesar 0.0000 dengan tingkat kepercayaan $95 \%$. Sehingga apabila apabila terjadi peningkatan PDRB per kapita sebesar satu rupiah dengan asumsi bahwa variabel independen yang lain tetap maka akan berpengaruh positif terhadap pertumbuhan ekonomi sebesar 4.38e-07\%. Dengan kata lain apabila terjadi peningkatan pada PDRB per kapita sebesar satu rupiah maka akan meningkatkan pertumbuhan ekonomi sebesar $4.38 \mathrm{e}-07 \%$.

Variabel independen APBD yang diproksi dari persentase APBD terhadap PDRB berpengaruh positif dan tidak signifikan terhadap variabel dependen pertumbuhan ekonomi dengan Prob $>\mathrm{t}$ lebih besar dari 0.05 yaitu sebesar 0.529 dengan tingkat kepercayaan 95\%.

Variabel independen inflasi yang diproksi dari PDRB deflator berpengaruh negatif dan signifikan terhadap variabel dependen pertumbuhan ekonomi dengan Prob $>$ t lebih kecil dari 0.05 yaitu sebesar
0.031 dengan tingkat kepercayaan 95\%. Sehingga apabila terjadi peningkatan pada laju inflasi sebesar satu persen dengan asumsi bahwa variabel independen yang lain tetap, maka akan berpengaruh negatif terhadap pertumbuhan ekonomi sebesar $0.4748451 \%$. Dengan kata lain apabila terjadi peningkatan inflasi sebesar satu persen maka akan menurunkan pertumbuhan ekonomi sebesar $0.4748451 \%$.

Variabel Independen FDI*H yaitu interaksi antara foreign direct investmen dengan human capital yang tersedia, berpengaruh positif tetapi tidak signifikan terhadap pertumbuhan ekonomi dengan Prob $>t$ lebih besar dari 0.05 yaitu sebesar 0.101. Sehingga apabila terjadi peningkatan pada jumlah tenaga kerja yang mampu menyerap FDI sebesar satu persen maka akan meningkatkan pertumbuhan ekonomi sebesar $0.0062149 \%$

Variabel independen investasi domestik yang diproksi dari persentase penanaman modal dalam negeri terhadap PDRB berpengaruh positif dan tidak signifikan terhadap variabel dependen pertumbuhan ekonomi dengan Prob $>$ t lebih besar dari 0.05 yaitu sebesar 0.888 dengan tingkat kepercayaan 95\%.

\section{Interpretasi Hasil}

Pengaruh FDI terhadap pertumbuhan ekonomi

Hubungan antara FDI dan pertumbuhan ekonomi dijelaskan dalam beberapa persamaan regresi seperti tabel dibawah ini:

Tabel 8. Hubungan antara FDI dan Pertumbuhan Ekonomi

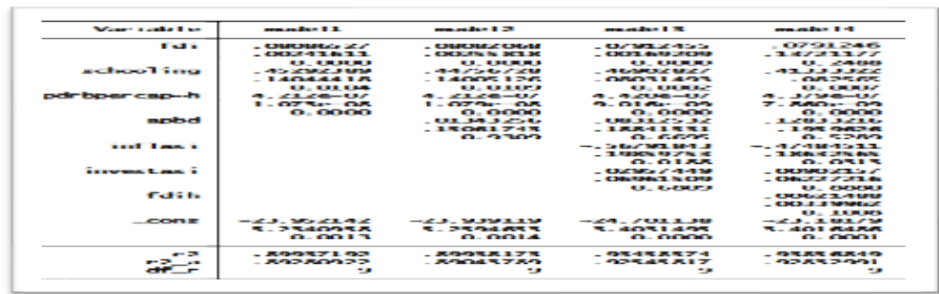


Hasil estimasi menunjukkan bahwa hubungan antara FDI tidak signifikan terhadap pertumbuhan ekonomi. Peningkatan pada pertumbuhan FDI yang yang terus meningkat setiap tahunnya belum mampu mempengaruhi sepenuhnya meningkatkan pertumbuhan ekonomi. Berdasarkan teori pertumbuhan endogen, pertumbuhan ekonomi tidak hanya dipengaruhi oleh jumlah modal akan tetapi ada faktor lain yang juga penting yaitu sumber daya manusia, dan teknologi (Dornbuch, 2008).

Hal ini disebabkan karena, sumber daya manusia yang tersedia memiliki rata-rata pendidikan yang ditamatkan masih rendah, sebagian besar memiliki tingkat pendidikan SD dan SMP, kemudian disusul dengan tingkat SLTA, sedang jumlah sumber daya manusia dengan pendidikan terakhir universitas masih sangat sedikit, seperti gambar dibawah ini.

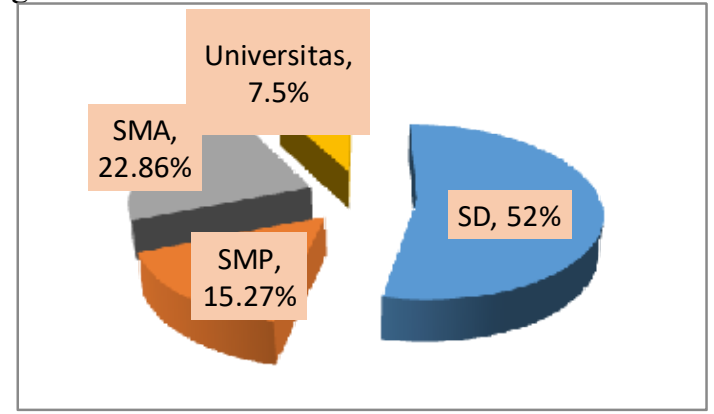

Gambar 2. Penyerapan Tenaga Kerja (BKPM, 2017 data diolah)

Meskipun FDI terus mengalami peningkatan setiap tahunnya, kemampuan menyerap tenaga kerja sangat kecil yaitu sebesar $1.84 \%$ hal ini karena kulitas sumber daya yang tersedia tidak sesuai dengan kriteria yang dibutuhkan oleh perusahaan. Kesiapan provinsi NTB dalam menyerap manfaat yang dapat diperoleh dengan adanya FDI selain adanya peningkatan stok modal yang masuk yaitu adanya transfer teknologi yang dibawa oleh perusahaan tersebut yang akan berdampak pada peningkatan softskill para tenaga kerja belum dapat terpenuhi. Sehingga kemungkinan besar FDI yang masuk memperkerjakan sumber daya manusia asing dalam kegiatan opresionalnya maupun menarik tenaga kerja dalam negeri tetapi berasal dari daerah diluar NTB. Adanya investasi asing langsung menandakan bahwa lapangan pekerjaan semakin luas dan bertambah akan tetapi setiap perusahaan memiliki syarat tertentu dalam melakukan perekrutan karyawan sesuai dengan kebutuhan perusahaan. Sifat yang saling melengkapi antara FDI dan modal manusia akan mendorong pertumbuhan ekonomi apabila tenaga kerja yang tersedia memadai.

FDI merupakan saluran utama untuk mengakses kemajuan teknologi yang diterapkan oleh negaranegara maju. Akan tetapi penerapan teknologi yang lebih maju mensyaratkan tingkat modal manusia yang cukup dan mampu dalam menyerap teknologi yang masuk. Penerapan teknologi maju dan kemampuan penyerapan oleh sumber daya manusia merupakan faktor penentu pertumbuhan ekonomi. Sehingga adanya interaksi yang kuat antara FDI dengan modal manusia yang tersedia terhadap peningkatan petumbuhan ekonomi. (E.Borenztein et al, 1998)

Adanya transfer teknologi mungkin terjadi melalui pembibingan dan perekrutan terhadap pegawai lokal. Akan tetapi perekrutan terhadap lulusan pada tingkat SLTA sebagian besar digunakan oleh perusahaan multinasional sebagai buruh, bukan pekerja professional sehingga tidak berpengaruh terhadap pertumbuhan ekonomi. FDI yang bersifat export oriented masih berinvestasi besar dalam training yang diberikan kepada pegawai lokal. Mengingat standardisasi kualitas yang harus dimiliki oleh produk yang dikeluarkan FDI berorientasi ekspor. Dengan training yang diberikan oleh FDI, setidaknya para pekerja telah memiliki keterampilan yang dapat ditiru atau dipraktekkan secara langsung atau ketika mereka sudah tidak bekerja di perusahaan asing tersebut. Jika FDI ini kelak tidak ada lagi di daerahnya, dampaknya terhadap keterampilan pekerja akan berkelanjutan

\section{Kesimpulan}

Berdasarkan pembahasan pada bab sebelumnya mengenai pengaruh foreign direct investment terhadap pertumbuhan ekonomi di provinsi NTB tahun 2010-2014. Menggunakan data panel dengan metode analisis fixed effect pada stata versi 11.1 dapat disimpulakan bahwa:

1. Foreign Direct Investment secara langsung berpengaruh secara positif dan signifikan terhadap pertumbuhan ekonomi di provinsi NTB tahun 2010-2014 dengan nilai $\mathrm{P}>|\mathrm{t}|$ lebih kecil dari 0.05 yaitu sebesar 0.000 . Hal ini disebabkan karena adanya FDI mendorong peningkatan ekspor pada provinsi Nusa Tenggara Barat. Secara tidak langsung foreign Direct Investmet setelah adanya interaksi terhadap sumber daya manusia maka FDI berpengaruh positif akan tetapi tidak signifikan dengan nilai $\mathrm{P}>|\mathrm{t}|$ lebih besar dari 0.05 yaitu sebesar 0.2488 terhadap pertumbuhan ekonomi. Karena kecilnya tenaga kerja yang mampu menyerap adanya FDI, hal ini disebabkan stok modal manusia yang ada di Prov. NTB sebagian besar memiliki tingkat pendidikan akhir yang ditamatkan adalah SD dan SMP. Oleh karena itu tenaga kerja yang ada belum mampu menyerap transfer teknologi yang disebabkan adanya FDI

2. Human Capital berpengaruh positif dan signifikan terhadap pertumbuhan ekonomi 
dengan nilai $\mathrm{P}>|\mathrm{t}|$ lebih kecil dari 0.05 yaitu sebesar 0.007. Hal ini disebabkan karena struktur perekonomian NTByang masih didominasi oleh sektor pertanian memiliki kontribusi besar dalam menyerap tenaga kerja yang tersedia. Sehingga sebagian besar angkatan kerja yang tersedia bekerja pada sektor pertanian dan mampu memberikan kontribusi dalam meningkatkan pertumbuhan ekonomi.Human capital yang dihasilkan oleh interaksi antara FDI dengan sumber daya manusia berpengaruh positif dan tidak signifikan terhadap pertumbuhan ekonomi di Prov. NTB. Hal ini disebabkan kecilnya jumlah tenaga kerja yang mampu menyerap adanya transfer teknologi yang dibawah oleh FDI masih rendah dibandingkan seluruh tenaga kerja yang tersedia.

\section{Saran}

Berdasarkan pembahaan dan beberapa kesimpulan diatas mengenai pengaruh Foreign Direct Investment terahap pertumbuhan ekonomi saran yang dapat diberikan oleh penulis antara lain:

1. Peningkatan FDI setiap tahunnya berpengaruh dalam peningkatan ekspor di Prov. NTB sehinggahal inilah yang mendorong pertumbuhan ekonomi. Akan tetapi kemampuan penyerapan sumber daya manusia terhadap teknologi yang dibawa oleh FDI belum maksimal karena tingkat pendidikan tenaga kerja yang tersedia tidak sesuai dengan kebutuhan FDI, sehingga perlunya upaya dari pemerintah untuk mendorong atau meningkatkan kualitas sumber daya manusia terutama dalam peningkatan pendidikan dan Skill masyarakat. Sehingga masyarakat mampu menerima manfaat dari adanya FDI dan dapat berkontribusi secara signifikan terhadap pertumbuhan ekonomi

2. Struktur perekonomian yang masih didominasi oleh sektor pertanian, pariwisata, serta pertambangan terhadap PDRB dan terbukti dengan kemampuan penyerapan tenaga kerja yang sebesar. Sehingga perlunya peran dari pemerintah untuk mendorong serta meningkatkan kegiatan investasi baik itu investasi domestik maupun investasi asing langsung pada sektor perekonomian yang lain sehingga dapat meningkatkan produktifitas dan memberbesar peran terhadap pertumbuhan ekonomi.

\section{Daftar Pustaka}

Agma Fachriza, Syafaat. 2015. Peran Foreign Direct Investment terhadap Pertumbuhan Ekonomi di Indonesia. (Februari 2015). Malang.

Borensztein, E. 1998. How Does Foreign Direct Investment Affect Economic Growth. Hal. 115-135 (February 1998). Korea.

\section{BKPM-Provinsi NTB (http://bkpm- ptsp.ntbprov.go.id)}

Colen, Liesbeth. 2008. Foreign Direct Investment As An Engine For Economic Growth and Human Development : A Review of The Arguments and

Empirical Evidence. No 16 (September 2009). U.K

David Lembong, John. 2013. Analisi Pengaruh PDB, Inflasi, Suku Bunga Dan Krisis Moneter Terhadap FDI di Indonesia Tahun 1981-2012. Journal Of Economics, Vol.2, No.4, Hal. 1-10. Semarang.

Demirhan, Erdal. 2008. Determinants of Foreign Direct Investment Flows To Developing Contries : A Cross-Sectional Analysis. Papers,4, 2008. Prague.

Dornbusch, Rudiger. 2008. Makroekonomi (Terj. Roy Indra Mirazudin). PT. Media Global Edukasi.

Fahmi Lubis, Ismail. 2012. Analisi Hubungan Antara Inflasi dan Pertumbuhan Ekonomi : Kasus Indonesia. QE Journal, Vol. 03, No.01-42. Sumatera Utara.

Islamoglu, Mehmet. 2015. Determination of Factors Affecting Individual Investor Behaviours : A Study on Bankers. International Journal of Economics and Financial Issues, Vol. 5 Issue 2, 531-543. 2015.

Kajian ekonomi regional Nusa Tenggara Barat tahun 2014

Kajian Ekonomi dan Keuangan Daerah Prov.NTB, 2014

Katerina, Lyroudi. 2004. Foreign Direct Investment and Economic Growth In Transition Economies. Journal of economics, Volume1, Hal. 97-110 (May 2004). South Eastern Europe.

Kholis, Muhammad. 2010. Dampak Foreign Direct Investment Terhadap Pertumbuhan Ekonomi Indonesia : Studi Makroekonomi dengan Penerapan Data Panel. Volume 8, Nomor 2, Hal.111-120 (September 2012). Surakarta. 
Latip, Dedi. 2009. Analisis Pengaruh Penanaman Modal Asing (FDI) Terhadap Pertumbuhan Ekonomi Regional Provinsi 200-2006. (Desember, 2009). Depok.

Lubis, Rizky P. 2015. Faktor-Faktor Yang Mempengaruhi Investasi Asing Pada Sektor Perkebunan di Indonesia. Jurnal Bisnis dan Manajemen, Vol.XVI, No.2, Hal. 80-89. Bogor.

Luiz, Jhon. 2009. Faktors Influencing Foreign Direct Investment of South African Financial Services Firms in Sub-Saharan Africa. Working Paper number 118 (March 2009). South African.

Mankiw, N. Gregory. 2008. Macroeconimic. Fifth Edition. Maryaningsi, Novi. 2014. Pengaruh Infrastruktur Terhadap Pertumbuhan Ekonomi. Buletin Ekonomi Moneter dan Perbankan, Vol.17 Nomor 1 (Juli 2014)

Marshal Obamuyi, Tomola. 2013. Faktors Influencing Investment Decisions in Capital Market : A study Of Individual Investors in Nigeria.Organizations and Market in Emerging Economies. Vol. 2, No.1(7). Nigeria

Masoud, Najeb. 2014. A Contribution to the Theory of Economic Growt: Old and New. Journal Of Economics and International Finance. Vol.6, 47-61 (March 2014). Jordan.

M. Romer, Paul. 1990. Endegoneus Technological Change. Journal of Political Economy, Vol.98, No.5, University of Chocago.

M. Sollow, Robert. 1994. Perspectives on Growth Theory. Journal of Economics Perspective, Vol.8, Number 1.
Naukoko, Amran. 2014. Analisis Faktor-Faktor yang Mempengaruhi Investasi di Kabupaten Sorong tahun 2008-2012. Volume 14 No. 3 (Oktober 2014). Manado.

Salsabila, Amira. 2011. Pengaruh FDI dan Modal Manusia terhadap Pertumbuhan Ekonomi antar Daerah di Indonesia. Depok

Sukirno, Sadono. 2013. Makroekonomi.

Sutawijaya, Adrian. 2013. Faktor-Faktor Yang Mempengaruhi Investasi Swasta di Indonesia. Volume 12, No. 1, Hal. 32-39 (Juni 2013). Tanggerang Selatan.

Vinh Vo, Xuan. 2009. The Importance of Social Factors When Assesing The Impact of Foreign Direct Investment on Economic Growth. No. 79 (September 2006). Sydney Australia.

Widowati Sugiharto, Lea. 2014. Dinamika PMA dan PMDN di Indonesia Sebagai Dampak dari Upah Minimum, Inflasi Dan PDRB tahun 2004-2012.Volume XVII, No. 3 (Desember 2014).

Yunan. 2009. Faktor-faktor yang Mempengaruhi Pertumbuhan Ekonom Indonesia. (September 2009). Medan.

Yang, Xianming. 2011. Factors Affecting FirmLevel Investment and Performance in Border Economic Zone and Implications for Developing Cross Border Economic zones Between the People's Republic of Cina and its Neigboring GMS Countries. Asian Development Bank, Volume No.1, Issue No 